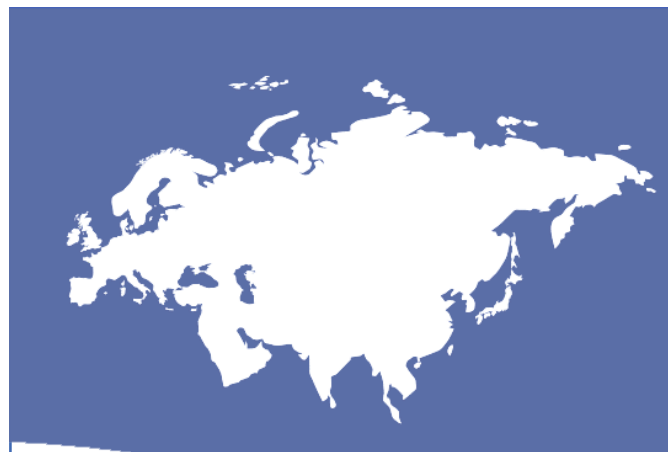

SLOVENIAN DOCUMENT ON DISMEMBERMENT OF BOSNIA-HERZEGOVINA CONFIRMS THE NECESSITY OF CONTINUING THE PIC-OHR-BONN POWERS

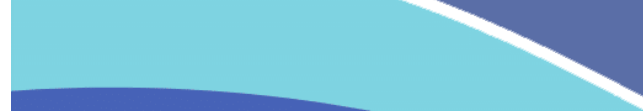

Analysis No : $2021 / 18$
Teoman Ertuğrul TULUN

\title{
30.04 .2021
}

Analyst

\subsection{4 .2021}

In our recent AVIM analysis titled Why Should the Role of the Peace Implementation Council and OHR Continue in Bosnia And Herzegovina?, we asserted the view that the continuation of the powers of the Peace Implementation Council (PIC), including the Bonn Powers, is essential for the preservation of the sovereignty and territorial integrity of Bosnia-Herzegovina $(\mathrm{BiH})$ within the framework of its constitution.[1] In this context, we underlined that Turkey, as a member of the PIC Steering Board, has the ability as well as the responsibility as a Balkan state with exceptional ties with $\mathrm{BIH}$, to influence the shaping of the decisions to be taken regarding the continuation of OHR. We further stressed that Turkey, in this process, as it did in the past, should staunchly defend the sovereignty and territorial integrity of $\mathrm{BiH}$ and must strongly oppose the approaches that aim to dismember $\mathrm{BiH}$.

Before the ink of our analysis dries up, we came across an irritated press report claiming that Slovenian Prime Minister Janez Jansa has sent a document to Charles Michel, President of the European Council, proposing the re-drawing of BiHs borders. It was reported by the media that Janez Janša has handed over a non-paper to the President of the European Council containing the upcoming Slovenian EU presidency priorities, which includes guidelines about the final disintegration of Yugoslavia. The said press reports also include the details of the claims that Željko Komšić, the Croat Presidency member, of $\mathrm{BiH}$ confirmed to local media that Slovenian President Borut Pahor had asked a similar question to the BiH Presidency members of Milorad Dodik, Šefik Džaferović (Şefik Caferoviç) and Željko Komšić in an informal conversation during his official visit on 5 March 2021 to $\mathrm{BiH}$. As per reports, Komšić stated that Pahor asked a question whether a peaceful separation in $\mathrm{BiH}$ is possible referring to the secession of the entity of Republika Srpska (RS) from the BiH. According to Komšić, in response to this question, he and Bosniak member Džaferović had replied this was not possible, while Serb member Dodik gave the opposite answer.[2] Both Slovenian President and Prime Minister, according to 
press reports, dismiss claims that they advocate the dissolution of Bosnia, or the redrawing of its borders.[3]

Despite these denials, a copy of the alleged document handed over to EU was published in the Slovenian investigative and journalistic online news outlet necenzurirano.si.[4] The mentioned news outlet claims that it published the document without any censorship. It is claimed that the document is entitled "Western Balkans[5] - The way forward" was received in Michel's cabinet in February. The authors are unknown. According to sources of the mentioned news outlet, it was certainly not created at the Slovenian Ministry of Foreign Affairs. Part of its content was allegedly written in Budapest. Nevertheless, it is referred to in Brussels diplomatic circles as a "Slovenian" document, as Janša's cabinet is said to have participated in sending it to various addresses.

The non-paper type document, under the solutions sub-title, contains the highly dangerous and adventurous suggestions regarding changing the borders in the Balkans which are reflected verbatim hereunder:

- The Unification of Kosovo and Albania. In Kosovo, 95\%of the population want to unite with their Albanian nation of origin. The situation is similar in Albania. The border between Albania and Kosovo de facto does not exist. The Serbian part of Kosovo would be given special status (following the model of South Tyrol).

- Joining a large part of the Republica of Srpska territory with Serbia. The Serbian national issue can be largely solved by joining a large part of the Republica Srpska with Serbia. In this case, Serbia is willing to agree on joining Kosovo with Albania.

- The Croatian national issue can be resolved by joining the predominantly Croatian cantons in the Bosnia-Herzegovina with Croatia or by granting special status to Croatian part of Bosnia-Herzegovina (using South Tyrol as a method)

- Bosniaks will thus gain an independently functioning state and responsibility for it. A referendum is organized for the people to choose between an EU and a non-EU (Turkey) future. For the time being, a convincing majority of Bosniaks support the EU perspective but, in the case of the continuation of the chaos and an increasingly stronger influence of Turkey and radical Islam, the situation can drastically deteriorate over the next decade. (Bold emphasis added)

The non-paper in its Steps sub-heading, among other, states the following.

- In a silent procedure, the possibility to implement the plan are checked with decision-makers in the region (underway)

- In a silent procedure, support for the plan is checked with the decision-makers in the international community (underway)

- If the EU, the United States and the majority of regional decision-makers agree with the plan and steps for its implementation, the EU seizes the initiative and formalise it.

It is understood that such an ill-intentioned plan, which could bear the potential to drag not only the Balkans but also the whole of Europe into the swamp of war seems to be 
prepared by Slovenia. The terminology in the plan reveals that contacts were made for the implementation of the plan. The references to Turkey in the document reflect entirely a hostile content. Bosnia-Herzegovina is shamelessly trying to be deleted from the European map. Muslim Bosniaks are tried to be prisoned in a small enclave. The plan, in a word, reflects hostility against Muslims and Turks.

The EU has not denied the existence of the report to date. However, the US has rejected this Slovenia-linked plan to break up Bosnia-Herzegovina. A state department spokesperson said on 15 April 2021 that "The United States deeply values its longstanding partnership with Bosnia and Herzegovina and supports its sovereignty and territorial integrity, respect for which was enshrined in the Dayton Peace Accords."[6]

It is worrisome that such a malicious plan has been prepared and studied in the EU. It is also alarming that the name of a NATO member country that will assume the EU presidency is associated with this plan. There is no doubt that Turkey will continue to defend in every platform including the PIC Steering Board the sovereignty and territorial integrity of the Bosnia-Herzegovina. It is believed that it would be useful that Turkey opens this issue up in the PIC Steering Board meetings and ask clarification from the EU representatives.

As the controversy regarding the Slovenia-linked non- paper continue, the new claims are made regarding the border changes in the Balkans that deserve to be followed diligently. In this vein, according to press reports, the Kosovan daily newspaper Koha Ditore published claims that Kosovo and Serbia would recognise each others territorial integrity and sovereignty under an EU deal by by Germany and France.[7] It is asserted in the report that an autonomous district of northern Kosovo would be created, while the Serbian Orthodox would have a privileged status. In return, Serbia would not hinder Kosovos membership in international organizations and Kosovo would not impose trade barriers. German and French Embassies to Kosovo denied involvement of their countries in this intrigue. German Ambassador to Kosovo tweeted: The so called German-French non paper published by Koha Ditore is fake news! There might be a paper but its for sure not a German- French one. Our full support is for the EU-led dialogue led by EUSR.[8] Additionally, the European Commission has also dismissed the report and stated that the alleged document does not express EU positions and was not received by the European Commission nor the European External Service.[9]

In addition to these statements, as per the media reports, the NATO Secretary General Jens Stoltenberg after his meeting with North Macedonian President Stevo Pendarovski at NATO headquarters in Brussels made a statement to the press regarding the unofficial document allegedly prepared by Slovenia. He said that "Speculations about changing the borders adds to the uncertainty and creates the risk of instability in the region. "[10] In this respect, North Macedonian President Pendarovski said that changing the borders in the Balkans would lead to a "blood bath". Pendarovski also expressed the view that the authors of these texts preferred to remain anonymous, and this was evidence that they were ashamed of their own ideas.[11]

When the developments summarized above are considered together, it seems that an 
idea assuming stability can be achieved by changing the borders in the Balkans is being tried to be tested. This testing of the ground seems to be carried out by some EU member countries. When the so-called non-papers about border changes leaked to the media, none of these countries took the responsibility, preferrring to leave their assertive papers orphaned and playing a shadow game.

As the Center for Eurasian Studies (AVIM), we can state that this is an extremely dangerous game. We are going through times when the Balkans and Europe need more security and stability than ever before. In such a period, it is beneficial to act in restraint and avoid stirring up hard-to-solve problems for the international community.

*Photo: necenzurirano.si

[1] Teoman Ertuğrul Tulun, Why Should The Role Of The Peace Implementation Council And OHR Continue In Bosnia And Herzegovina?, Center For Eurasian Studies (AVIM) 2021, no. 14 (April 6, 2021): 7, https://avim.org.tr/en/Analiz/WHY-SHOULD-THE-ROLF-OF-THEPEACE-IMPLEMENTATION-COUNCIL-AND-OHR-CONTINUE-IN-BOSNIA-AND-HERZEGOVINA.

[2] Zeljko Trkanjec, Slovenia Suspected of Seeking Peaceful Dissolution of BosniaHerzegovina, Euroactiv, April 13, 2021, https:/www.euractiv.com/section/enlargement/news/slovenia-suspected-of-seekingpeaceful-dissolution-of-bosnia-herzegovinal.

[3] Anja Vladisavljevic, Slovenian Leaders Deny Calling for Dissolution of Bosnia, Balkan Insight, April 12, 2021, sec. News, https://balkaninsight.com/2021/04/12/slovenian-leadersdeny-calling-for-dissolution-of-bosnial.

[4] Primož Cirman and Vesna Vuković, Objavljamo dokument o razdelitvi BiH, ki ga išče ves Balkan, April 15, 2021, sec. Aktualno, https://necenzurirano.si/clanek/aktualno/objavljamo-slovenski-dokument-o-razdelitvi-bih-kiga-isce-ves-balkan-865692.

[5] AViM considers the term "Western Balkans" to be a politically motivated separatist terminology and persists on the use of the geographical and historical identification "Balkans" regarding the region.

[6] Andrew Rettman and Ekrem Krasniqi, US Rejects Slovenia-Linked Plan to Break up Bosnia, EU Observer, April 16, 2021, sec. EU \& The World, https://euobserver.com/world/151572. 
[7] Matthew Holroyd and Milos Milic, EU, France and Germany Play down Serbia-Kosovo Deal Reports, Euronews, April 28, 2021, sec. Wold, https://www.euronews.com/2021/04/28/eu-france-and-germany-play-down-serbia-kosovodeal-reports.

[8] EWB, Another Alleged Non-Paper Proposes the Conclusion of Kosovo-Serbia Normalisation Process by 2022, European Western Balkans, 297April 2021, sec. Politics, https://europeanwesternbalkans.com/2021/04/27/another-alleged-non-paper-proposes-theconclusion-of-kosovo-serbia-normalisation-process-by-2022/.

[9] Holroyd and Milic, EU, France and Germany Play down Serbia-Kosovo Deal Reports.

[10] Ömer Tuğrul Çam, NATO: Balkanlarda sınır değişikliğiyle ilgili spekülasyonlar istikrarı bozar, Anadolu Haber Ajansı, April 28, 2021, sec. Dünya, https://www.aa.com.tr/tr/dunya/nato-balkanlarda-sinir-degisikligiyle-ilgili-spekulasyonlaristikrari-bozar/2223362\#.

[11] Kuzey Makedonya Cumhurbaşkanı: Balkanlarda Sınırlar Değiştirilirse Ortalık Kan Gölü Olur, Euronews, April 28, 2021, sec. Dünya, https://tr.euronews.com/2021/04/28/kuzeymakedonya-cumhurbaskan-balkanlarda-s-n-rlar-degistirilirse-ortal-k-kan-golu-olur.

About the Author:

Teoman Ertuğrul Tulun is an analyst at Ankara-based think-tank Center for Eurasian Studies. He is a PhD Candidate at Bilkent University Department of Political Science and Public Administration. His area of research include European Union Studies, Social Movements, Xenophobia and Hate Speech Studies and State Building Studies. 
To cite this article: TULUN, Teoman Ertuğrul. 2021. "SLOVENIAN DOCUMENT ON DISMEMBERMENT OF BOSNIA-HERZEGOVINA CONFIRMS THE NECESSITY OF CONTINUING THE PIC-OHR-BONN POWERS." Center For Eurasian Studies (AVIM), Analysis No.2021 / 18. April 30. Accessed October 19, 2021. https://avim.org.tr/en/Analiz/SLOVENIAN-DOCUMENT-ON-DISMEMBERMENT-OF-BOSNIA-HERZEGOVINACONFIRMS-THE-NECESSITY-OF-CONTINUING-THE-PIC-OHR-BONN-POWERS

\section{(2) AVIM}

Süleyman Nazif Sok. No: 12/B Daire 3-4 06550 Çankaya-ANKARA / TÜRKIYE

Tel: +90 (312) 43850 23-24 • Fax: +90 (312) 4385026

@avimorgtr

7 https://www.facebook.com/avrasyaincelemelerimerkezi

E-Mail: info@avim.org.tr

http://avim.org.tr

(C) 2009-2021 Center for Eurasian Studies (AVIM) All Rights Reserved 